\title{
Management of Diabetes Mellitus Type 2 for Elderly: Taichi Exercise to Reduce Blood Sugar Levels
}

\author{
Fahruddin Kurdi ${ }^{*}$, Zainal Abidin², Ratna Puji Priyanti ${ }^{3}$, Anja Hesnia Kholis ${ }^{4}$
}

\author{
1Department Community Nursing, Faculty of Nursing, University of Jember, Indonesia; \\ fahruddin.fkep@unej.ac.id (Corresponding Author) \\ 2Prodi D3 Keperawatan Kampus Lumajang, Faculty of Nursing, University of Jember, Indonesia \\ 3,4STIKES Pemkab Jombang, Indonesia
}

\begin{tabular}{ll}
\hline Article Info: & ABSTRACT \\
Submitted: & Elderly are high risk for the development of type 2 diabetes due to the combined \\
07-08-2021 & effects of increasing insulin resistance and impaired pancreatic function with aging. \\
Revised: & Diabetes mellitus is a chronic disease that causes insulin in the pancreas is not \\
29-09-2021 & effective one of the treatments that can be done by diabetics to reduce blood sugar \\
Accepted: & levels One of them with physical activity, the activity is taichi exercises. The purpose of \\
02-10-2021 & this study was to investigate the effect of taichi exercises on reducing blood sugar \\
& levels in patients with type II diabetes mellitus. The design of this study was pre- \\
& experiment one group pre-test and post-test design with a population of 88 patients \\
& and a sample of 44 respondents. Research sampling technique used purposive \\
& sampling. Data collection with observation sheets. The intervention was carried out \\
& four times during 4 weeks. Before the intervention, sugar levels of type II diabetics \\
DOI: & were classified as moderate as 24 people (54.5\%) and high as many as 20 people \\
https://doi.org/10.53713/nhs.v1i2.51 & (45.5\%). After the management of taichi exercises sugar levels experienced changes \\
& in the categories of good as many as 16 people (36.4\%), moderate as many as 20 \\
& people (45.5\%) and high as many as 8 people (18.2\%). Data analyzed with Wilcoxon \\
& Signed Rank test with a significant level a $=0.05$, the result $\rho$-value $=0.001$ means $\rho-$ \\
value <a so that there is a significant effect of taichi exercises on decreasing blood \\
sugar levels in patients with type II diabetes mellitus. Blood sugar levels in patients \\
with diabetes mellitus before doing taichi exercises with the number of respondents 44 \\
people mostly experienced changes, evidenced by the level of blood sugar levels from \\
moderate levels to good.
\end{tabular}

under CC BY-SA License.
Keywords: Elderly, Taichi, Diabetes Mellitus, Blood sugar level

\section{INTRODUCTION}

An estimated $33 \%$ of adults aged 60 or older have diabetes. This population is more at risk of developing diabetes-related complications like hypoglycemia, kidney failure and heart disease than younger people living with diabetes. Diabetes mellitus is non-communicable disease that can secretly damage the body's and cause several complaints, so it is referred to as diabetes mellitus or often referred to as diabetes, which is a chronic disease that occurs Because the pancreas does not produce insulin, the body cannot effectively use the insulin produced by the pancreas.

One of the physical activities that can be done is taichi which can have many health benefits. Taichi may be an attractive alternative to aerobics because the practice requires little space, does not require equipment to practice, and has few side effects. The success of the intervention of taichi elements has been widely seen in heart disease and diabetes mellitus. Research has shown that the incorporation of taichi therapy in the treatment of diabetes mellitus has resulted in reduced doses of hypoglycemic agents and insulin, weight control, improved glucose tolerance, and reduced hyperglycemia (Indah, 2015).

According to WHO data, between 2000 and 2016 there was a 5\% increase in premature mortality from diabetes. The number of people with diabetes mellitus in 2015 reached 415 million people. This figure is predicted to increase to 642 million people by 2040, with an increase of 55\% (IDF-DAR, 2016). In 2013 and East Java province with diabetes mellitus sufferers of $2.5 \%$ from $2.0 \%$ in 2013. According to the 2014 Sample Registration Survey (SRS) diabetes mellitus is the number 3 cause of death in Indonesia with a percentage of $6.7 \%$ (Kemenkes RI, 2017). Sumbersari District is a 
sub-district with the hight prevalence of diabetes in Jember Regency. Based on data from the Health Office Jember in 2018 there was 699 visits Diabetes Mellitus patient at Sumbersari Public Health Center (Qashuraini, 2018).

Taichi exercice has also been studied to control both the symptoms and complications associated with type II diabetes mellitus. The study showed a statistically significant role for taichi therapy in the control of diabetes mellitus. Furthermore, taichi exercice showed a significant improvement for diabetes mellitus patients with pre-existing complications. Type II diabetes mellitus is a problem in the body because of the decreased ability of cells to accept insulin which is called insulin resistance (Hovaguimian, 2011). Kiadaliri et al (2013) explained that people with type II diabetes mellitus did not know any symptoms beforehand. However, the clinical manifestations of type II diabetes mellitus include: classic symptoms such as polyuria, polydipsia, polyphagia, and weight loss, blurred vision, paresthesias in the lower extremities, fungal infections, for example in balanitis in men.

The solution to reduce blood sugar levels in diabetic patients within normal limits requires an approach from various disciplines in the form of collaboration with doctors, nurses, laboratories, physiotherapists, and nutritionists. Counseling on how to control diabetes, nutritional status, regular general condition checks are ways to control blood sugar in diabetic patients. In addition, the implementation of taichi exercises will affect the decrease in blood sugar levels within normal limits. Nurses play an important role in teaching the correct way of taichi exercise, so that it can have a significant effect in lowering blood sugar levels to normal limits, if blood sugar is within normal limits, eating will save patients from diabetes complications which are still a scourge for diabetics. mellitus (Tambunan, 2011), based on the above phenomenon, researchers are interested in conducting a study entitled the effect of taichi exercise on reducing blood sugar levels in patients with type II diabetes mellitus.

\section{METHOD}

This study uses a pre-experimental design, the type of research used is a one group pre-test-post-test design. The research was conducted in Sumbersari, Jember Indonesia in 2021. The population of this research is 88 people with diabetes mellitus, using the non-probability sampling technique with purposive sampling obtained a sample of 44 people. The collected data is processed through the stages of editing, coding, scoring, and tabulating and using non-parametric analysis with the Wilcoxon test.

\section{RESULT}

\section{The characteristic of respondents}

Table 1. Distribution of respondents based on the age, education, gender, job, and information $(n=44)$

\begin{tabular}{lcc}
\hline \multicolumn{1}{c}{ Characteristics } & Frequency & Percentage \\
\hline Age & & \\
middle age (45-59) & 6 & 13.6 \\
elderly (60-74) & 16 & 36.4 \\
old (75-90) & 22 & 50.0 \\
very old (>90) & 0 & 0 \\
\hline Education level & & \\
Basic & 20 & 45.5 \\
Moderate & 20 & 45.5 \\
High & 4 & 9.1 \\
\hline Sex & & \\
Male & 18 & 40.9 \\
Female & 26 & 59.1 \\
\hline Job & & \\
Farmer & 6 & 13.6 \\
Enterpreneur & 8 & 18.1 \\
Retired Civil & 4 & 9 \\
No Job & 16 & 35.4 \\
\hline Source of information & & \\
Health Provider & 40 & 83.3 \\
Mass Media & 0 & 0 \\
Electronic media & 4 & 16.7 \\
Other & 0 & 0 \\
\hline
\end{tabular}


Table 2. Blood sugar levels before and after doing taichi $(n=44)$

\begin{tabular}{ccccc}
\hline Blood & \multicolumn{2}{c}{ Pre } & \multicolumn{2}{c}{ Post } \\
\cline { 2 - 5 } Level & Frequency & Percentage & Frequency & Percentage \\
\hline Normal & 0 & 0 & 16 & 36.4 \\
Moderate & 24 & 54.5 & 20 & 45.5 \\
High & 20 & 45.5 & 8 & 18.2 \\
\hline Total & 44 & 100 & 44 & 100 \\
\hline
\end{tabular}

Table 2 shows that before doing taichi, the respondents with moderate blood sugar levels were 22 people $(54.5 \%)$ while those with high blood sugar levels were 20 people (45.5\%). After doing taichi, there were 16 respondents with normal blood sugar levels (36.4\%), 20 respondents with moderate blood sugar levels $(45.5 \%)$ and 8 respondents with high blood sugar levels $(18,2 \%)$.

Table 3. Cross tabs between blood sugar levels before and after doing taichi exercice

\begin{tabular}{|c|c|c|c|c|c|c|c|c|}
\hline \multirow{3}{*}{$\begin{array}{c}\text { Blood } \\
\text { level } \\
\text { before } \\
\text { exercise }\end{array}$} & \multicolumn{6}{|c|}{ Blood level After exercise } & \multirow{2}{*}{\multicolumn{2}{|c|}{ Total }} \\
\hline & \multicolumn{2}{|c|}{ Normal } & \multicolumn{2}{|c|}{ Moderate } & \multicolumn{2}{|c|}{ High } & & \\
\hline & Frequency & Percentage & Frequency & Percentage & Frequency & Percentage & Frequency & Percentage \\
\hline Normal & 0 & 0 & 0 & 0 & 0 & 0 & 0 & 0 \\
\hline Moderate & 16 & 66.7 & 8 & 33.3 & 0 & 0 & 24 & 100 \\
\hline High & 0 & 0 & 12 & 60.0 & 8 & 40.0 & 20 & 100 \\
\hline Total & 16 & 36.4 & 20 & 45.5 & 8 & 18.2 & 44 & 100 \\
\hline
\end{tabular}

Table 3 shows that most $(66.7 \%)$ respondents experienced changes in blood sugar levels before doing taichi exercise their blood sugar levels were getting better after doing taichi exercise, there are 16 respondents, and high $(60.0 \%)$ respondents experienced changes blood sugar levels before doing taichi exercise had high blood sugar levels to moderate after doing taichi exercise, there are12 respondents.

\section{Statistical Test Analysis of pain before and after doing taichi exercises}

To determine the effect of the independent variables on the dependent in the treatment group using the Wilcoxon signed rank test statistic. If the error level $=5 \%(0.00)$ the hypothesis $(\mathrm{Ho})$ will be rejected if $p \leq a$ which means there is an effect and will be accepted if the hypothesis ( $\mathrm{Ho}) \mathrm{p} \geq a$ which means there is no effect.

\begin{tabular}{cccc}
\multicolumn{4}{c}{ Table 4. Wilcoxon Signed Ranks Test statistical test results } \\
\hline$Z_{\text {score }}$ & $Z_{\text {table }}$ & $\rho$ value & Signicant $(\mathrm{a})$ \\
\hline-3.306 & -1.96 & 0.001 & 0.05 \\
\hline
\end{tabular}

Table 4 showing the results of the Wilcoxon Signed Ranks Test statistic, Zscore is -3.306 where the Ztable value with a significant level of $5 \%(0.05)$ with a two-tailed test is -1.96 this means that Zscore is greater than Ztable (Zscore> Ztable), that is $(-3.306>-1.96)$, then $\mathrm{H}_{0}$ is rejected. $\mathrm{P}$ value obtained, can be seen in Asymp. Sig. (2-tailed) that is value $=0.001$, where the value of value $<(0.05)$. From the results of the calculation value 0.001 is smaller than 0.05 then $\mathrm{H} 0$ is rejected. so it can be concluded that there is an effect of taichi exercise on reducing blood sugar levels in patients with diabetes mellitus type II.

\section{DISCUSSION}

\section{Identification Blood Sugar Levels in DM Type II Patients Before and After Taichi Exercise}

Based on table 2 shows that before doing taichi, respondents with moderate blood sugar levels were 24 respondents $(54.5 \%)$ while those with bad blood sugar levels were 20 respondents (45.5\%). Based on table 2 shows that the average blood sugar level of respondents before doing taichi exercise was $183.23 \mathrm{mg} / \mathrm{dl}$. Pre-test data showed that respondents in the study had glucose levels in the bad category, which was $>180 \mathrm{mg} / \mathrm{dL}$. This condition was caused by respondents have not carried out activities, where glucose is still not used as energy.

Based on table 3 shows that most (66.7\%) respondents experienced changes in blood sugar levels before doing taichi exercise their blood sugar levels were getting better after doing taichi exercise, there are 16 respondents in high 
blood sugar levels $(60.0 \%)$ respondents experienced changes in blood sugar levels which before doing taichi exercise had high blood sugar levels to moderate after doing taichi exercise, which was a total of 12 respondents.

According to Miganti (2012) suggests that blood sugar levels usually fluctuate, up and down throughout the day and at any time, depending on the metabolism of food into glucose by the body, and how the body manages glucose and increases after eating and returns within 2 hours. While a person is said to have diabetes if he has fasting glucose levels $>126 \mathrm{mg} / \mathrm{dl}$.

Factors that affect blood sugar levels, physical activity, diet and stress (Sukhee, 2012). Sedentary physical activity can also cause an increase in blood sugar levels. Physical activity is a movement that results from skeletal muscle contraction that requires an energy exceeding energy expenditure during rest. During exercise the muscles become more active where there will be an increase in membrane permeability and an increase in blood flow due to more open capillary membranes and more active insulin receptors, a shift in the use of energy by muscles from fatty acid sources to the use of glucose and muscle glycogen. The Journal of Endocrinology and metabolism explain that taichi is stated as an effective therapy for controlling the symptoms of diabetes mellitus (Wang et al, 2010).

Taichi is an alternative form of physical activity that is recommended for some individuals. Meditation, taichi and yoga, qi-gong, and other relaxation techniques, have been studied in diabetes as a means of reducing blood glucose levels (Khamida, 2018). This is in accordance with the results of research from (Kurdi \& Priyanti, 2019), which shows an effectiveness the exercises for manage glucose levels diabetic patients and prevent the risk of foot ulcers.

The results of research conducted by Devi, MS (2020) regarding the effect of diabetes mellitus exercise on blood sugar levels in diabetes mellitus type II patients stated that the main problem in diabetes mellitus type II is the lack of response to insulin (insulin resistance) so that glucose cannot enter the cells, to overcome insulin resistance in patients can be done by providing physical activity in the form of exercise.

Researchers argue that the main problem in diabetes mellitus type II is the lack of response to insulin (insulin resistance) so that glucose cannot enter the cells. This insulin resistance occurs due to genetic and environmental factors such as obesity, a high-fat, low-fiber diet, and lack of physical activity and aging.

\section{Blood sugar levels after taichi}

Table 2 shows that after doing taichi, there were 16 respondents with normal blood sugar levels $(36.4 \%), 20$ respondents with moderate blood sugar levels (45.5\%) and 8 respondents with high blood sugar levels (18.2\%). After doing taichi the average fell to $163.77 \mathrm{mg} / \mathrm{dl}$.

One of the sports for people with diabetes mellitus type II is taichi. Taichi exercise has benefits for controlling blood sugar levels. Taichi therapy is able to calm the mind, relieve stress, and maintain body fitness so that it can balance glucose levels in the blood. In taichi, we unite the mind and body into a balanced whole. Taichi is one of the oldest comprehensive health care systems in existence, which focuses on the mind and body (Khamida, 2018).

For people with diabetes mellitus, taichi practice is useful for lowering glucose levels in the blood, preventing obesity, as one of the healing factors for diabetes where the process plays a role in overcoming the possibility of blood lipid disorders, and increasing blood pressure. Thus, it can improve the quality of life of diabetics. Taichi can also stimulate a decrease in sympathetic nerve activity and an increase in parasympathetic nerve activity which affects the decrease in the hormones adrenaline, norepinephrine and catecholamines as well as vasodilation in blood vessels which results in smooth oxygen transport throughout the body, especially to the brain so that it can reduce blood pressure and pulse to normal. (Hikmaharida, 2011).

The results of the study after the intervention of giving taichi exercise to reducing blood sugar levels showed good impact, someone with diabetes usually has thick blood consistency due to the blood clotting process due to damage to an organ, therefore giving physical activity such as taichi exercise is good for diabetics because Taichi exercise is a physical activity that is not strenuous because it focuses on thoughts and feelings, so that feelings of anxiety and physical disturbances can be reduced.

\section{Analysis of the Effect of Taichi Exercise on Reducing Blood Sugar Levels in Type II Diabetes Mellitus Patients}

Table 3 shows that most $(66.7 \%)$ respondents experienced changes in blood sugar levels before doing taichi exercise their blood sugar levels were getting better after doing taichi exercise, there are 16 respondents, and most $(60.0 \%)$ respondents experienced Changes in blood sugar levels before doing taichi exercise had bad blood sugar levels to moderate after doing taichi exercise, there are 12 respondents.

Table 4 shows the results of the Wilcoxon Signed Ranks Test statistic that Zcount is -3.306 where the value of Ztable with a significant level of $5 \%(0.05)$ with a two-tailed test is -1.96 this means that Zcount is greater than Ztable (Zcount> Ztable ) that is (-3.306 > -1.96), then $\mathrm{HO}$ is rejected. value obtained, can be seen in Asymp. Sig. (2-tailed) that is value $=0.001$, where the value of value $<(0.05)$. From the results of the calculation value 0.001 is smaller than 0.05 
then $\mathrm{HO}$ is rejected. So it can be concluded that there is an effect of taichi exercise on reducing blood sugar levels in patients with diabetes mellitus type II.

Sedentary physical activity can also cause an increase in blood sugar levels. Physical activity is a movement that results from skeletal muscle contraction that requires an energy exceeding energy expenditure during rest. During exercise the muscles become more active where there will be an increase in membrane permeability and an increase in blood flow due to more open capillary membranes and more active insulin receptors, a shift in the use of energy by muscles from fatty acid sources to the use of glucose and muscle glycogen. (Holt \& Kumar, 2010).

There are many health benefits that can be obtained from taichi. Over time taichi will begin to change your diet and lifestyle instinctively to prevent the subconscious from destroying what has been painstakingly built so far. Some of the benefits that can be obtained from doing taichi are increasing strength, increasing flexibility, practicing balance, reducing pain, practice breathing, smooth organ function, inner peace, peace of mind, reduce depression and stress, alert the body, and increase concentration and intelligence (Agustiana, 2017).

The influence of taichi exercise on decreasing blood sugar levels is due to a systematic process using motion stimulation that aims to improve or maintain the functional quality of the body which includes the quality of lung and heart endurance, muscle strength and endurance, flexibility and body composition with continuous, rhythmic, progressive and continuous movement accompanied by music which is useful for increasing metabolism, timing of gymnastics, and speed of exercise. Regularity of taichi exercise provided by researchers can improve the health of people with diabetes mellitus because after 1 week of taichi exercise 2 times, the majority of blood sugar levels of people with diabetes mellitus decreased to maintain the stability of blood sugar levels.

According to Virginia Henderson's theory, Henderson also developed a nursing model known as "The Activities of Living". The model explains that the nurse's job is to help individuals by increasing their independence as soon as possible. Nurses carry out their duties alone, not dependent on doctors. However, the nurse still conveys the plan to the doctor when visiting the patient.

Whereas, from the results of the study, it was also found that 4 respondents did not experience a decrease in blood sugar levels after doing taichi exercise.

\section{CONCLUSION}

Blood sugar levels in patients with Type II Diabetes Mellitus before doing taichi exercise from 44 respondents, mostly in the high category, 20 respondents I (45.5\%). Blood sugar levels in patients with Diabetes Mellitus Type II after doing taichi exercise from 44 respondents, the blood sugar levels of respondents in the normal category were 16 respondents $(36.4 \%)$. There is an effect of taichi exercise on reducing blood sugar levels in patients with diabetes mellitus type II.

People, especially elderly people with diabetes mellitus, should doing exercise such as taichi exercise therapy regularly to maintain stable blood sugar levels and reduce the risk of complications of diabetes mellitus.

\section{REFERENCES}

Agustiana, L., \& Prabo, H. (2017). Pengaruh Senam Lansia (Tai Chi) Terhadap Penurunan Tekanan Darah Pada Lansia Penderita Hipertensi Di Upt Pelayanan Sosial Lanjut Usia Banyuwangi Tahun 2017. XLII(May), 22- 24. https://doi.org/10.5194/isprsarchives-XLII-5-W1-175-2017

Cahyono, K. (2013). Pengaruh Senam Lansia Terhadap Kualitas Tidur Pada Lansia Di Desa Leyangan Kecamatan Unggaran Timur Kabupaten Semarang. PREPOTIF Jurnal Kesehatan Masyarakat, 1(1)

Clevo, \& Margareth. (2012). Asuhan Keperawatan Medikal Bedah Dan Penyakit Dalam. Yogyakarta: Nuha Media

Devi, M.S. (2020). Hubungan Persepsi Penyakit Dengan Efikasi Diri Pada Pasien Diabetes Melitus Tipe 2 Di Poli Penyakit Dalam Rumah Sakit Tingkat III Baladhika Husada Jember. Skripsi. https://repository.unej.ac.id/bitstream/handle/123456789/102193

Dhania. (2009). Pengaruh Tingkat Pengetahuan Tentang Diabetes Mellitus Terhadap Kontrol Diri Pada Pasien Rawat Jalan Penderita Diabetes Mellitus. PANMED

Guyton, Arthur. C., \& Hall. John., E. (2008). Buku Ajar Fisiologi Kedokteran (11th ed.). Jakarta: EGC.

Hikmaharidha, I. (2011). Pengaruh Senam Tai Chi Terhadap Tekanan Darah Wanita Berusia 50 Tahun Ke Atas. http://eprints.undip.ac.id/33315/1//stifa.pdf

Holt, Tim \& Kumar, Sudhesh. (2010). ABC of Diabetes 6th Edition. UK: John Wiley \& Sons Ltd., Publication. International Diabetes Federation

Hovaguimian, A. (2011). Clinical approach to the treatment of painful diabetic neuropathy. Therapeutic Advances in Endocrinology and Metabolism, 2(1): 27-38. https://dx.doi.org/10.1177\%2F2042018810391900

Indah, P.Y. (2015). Pengaruh Senam Bugar Lansia Indonesia Terhadap Penurunan Kadar Gula Darah Pada Wanita Lansia. Skripsi : Universitas Negeri Semarang 
Kemenkes RI. (2017). Data Dan Informasi Profil Kesehatan Indonesia. Jakarta

Khamida. (2018). Senam Tai Chi dalam menurunkan kecemasan lansia. Jurnal Ners \& Kebidanan. $218-223$. https://doi.org/10.26699/jnk.v5i3.ART.p218

Kiadaliri, A.A., Najafi, B., Mirmalek-Sani, M. (2013). Quality of life in people with DM: a systematic review of study in Iran. Journal of Diabetes and Metabolic Disorders, 12(54). https://doi.org/10.1186/2251-6581-12-54

Kurdi, F., \& Priyanti R. P. (2019). Manajemen Ulkus Kaki Diabetikum: Efektifitas Foot Exercise Terhadap Risiko DFU (Diabetic Foot Ulcers) Pasien Diabetes Mellitus di Al Hijrah Wound Care Center. Jurnal IImiah PANNMED, 14(2), 95101. https://doi.org/10.36911/pannmed.v14i2.593

Qashuraini, Azza, A. Komarudin. (2018). The Relationship between Stress Level and Blood Sugar Level in Diabetes Mellitus Patients in the Work Area of Jember District Health Center. FIK Universitas Muhammadiyah Jember. http://repository.unmuhjember.ac.id/3882/10

Rudi A, K. H. (2013). Faktor Resiko Yang Memepengaruhi Kadar Gula Puasa Pada Pengguna Layanan Laboratorium. UNAIR Repository

Rumahorbo H. (2014). Mencegah Diabetes Mellitus Dengan Perubahan Gaya Hidup. Bogor : In Media

Soewondo, P. Perkeni. (2011). Konsensus Pengelolaan Dan Pencegah Diabetes Mellitus Tipe 2. Jakarta

Sukhee, A. (2012). Effects of Tai Chi Exercise on Glucose Control, Neuropathy Scores, Balance, and Quality of Life in Patients with Type 2 Diabetes and Neuropathy. Journal of Alternative and Complementary Medicine. 18(12): 1172-1178. https://dx.doi.org/10.1089\%2Facm.2011.0690

Tambunan, M. (2011). Perawatan Kaki Diabetes, Dalam : Penatalaksanaan Diabetes Melitus Terpadu. Jakarta : Fakultas Kedokteran Universitas Indonesia.

Wang C., Bannuru R., Ramel J., Kupelnick B., Scott T., and Schmid C. H. (2010). Tai Chi on psychological well-being: systematic review and metaanalysis. BMC Complementary and Alternative Medicine, 10, article 23. https://doi.org/10.1186/1472-6882$10-23$ 